\title{
The Application of Genre-based Teaching Approach in English Intensive Reading for Minority Preparatory Students
}

\author{
Hongxia Dai \\ Ethnic school, Nanchang Institute of Science and Technology \\ Nanchang, 330018, China \\ dhx8522@163.com
}

\begin{abstract}
I choose the text of Unit Twelve "Alex Haley" from Book 2 in English compiled by higher school teaching material compiling group in Education Ministry for Minority Preparatory students so as to introduce the application of genre-based teaching approach in English intensive reading for minority preparatory students. The study aims at improving teaching efficiency and enhancing the English level of students by the application of genre-based teaching approach in the teaching. The real cases of genre-based teaching approach in practices show that genre-based teaching approach gains affirmative praises from the teachers and the students, so genre-based teaching method can be used in English teaching for minority preparatory students.
\end{abstract}

Keywords-Genre-based Teaching Approach; Minority Preparatory Students; English Intensive Reading

\section{INTRODUCTION}

Genre-based teaching approach is a new teaching method in the middle of 1980s. In the latest decades, as a practical teaching method, genre-based teaching approach has come into the attention of education circles. Domestically, genre-based teaching approach is applied into English teaching by many English teachers in higher schools and obligatory education schools. However, the application of the approach in English teaching for minority preparatory students is far and few between. Therefore, I try to select a text as a case study to explore the application of the approach in English intensive reading for minority preparatory students.

In America, genre-based teaching approach is applied in college English teaching and English for special purposes. The process can be divided into six steps: genre analysis, imitation analysis, group discussion, independent analysis, deeper analysis and imitative writing [1] (Lan Ma, 2003). I use the process for reference. According to the characteristics of the intensive reading for preparatory courses students, I apply the genre-based teaching approach in the intensive reading as the teaching process shows as below:

(1) Genre analysis. A text is selected from the teaching material for preparatory courses students to analyze the genre and schema of the text. In the traditional grammar translation teaching approach, more attentions are paid to the learning of words, grammar and sentences [2]. Nevertheless, the students often voice their opinions to the teachers, "Why I can't understand the text or even a sentence while I know the words and expressions." Genre-based teaching approach combines grammar, context with situation. Since the text is one part of the social situations, the minority preparatory students have to have an understanding of the social background, history, culture and writing skills etc. if they want to master the content and structure of a chapter. Therefore, the teacher should lecture and explain all the knowledge to the students rather than explain words, phrases, sentences or paragraph simply so that they may be acquainted with the background information of the text.

(2) Deep analysis. The teacher analyzes the text in detail with the emphasis on words, grammar, rhetoric and writing style, etc. With such a lecture, the preparatory courses students have a better understanding of the reading passage and analyzing the text in future and can improve their writing skills in future study.

(3) Imitating analysis. The minority preparatory students are asked to apply genre-based analysis method to understand and analyze a different text belonging to the same genre. In this way, it is tested whether they have mastered genre-based approach and as a result, the application of genre-based approach is reinforced so that the independent learning ability is enhanced.

(4) Independent analysis. The preparatory courses students find a text of English intensive reading which belongs to the same genre to analyze and learn it on their own. By independent analysis, the learning efficiency of them can be tested and whether the approach is suitable for their learning can also be seen. Their learning abilities by themselves can be improved at the same time.

In the teaching, the teacher has to finish (1) and (2) while (3) and (4) are arrange to be completed by the preparatory courses student after class.

Foundation program: Teaching Reform Research Project of Nanchang Institute of Science and Technology: The Application of Genre-based Teaching Approach in English Intensive Reading for Minority Preparatory students (NGJG-16-16) 


\section{An ANALysis on TEACHING CASE}

I choose the text of Unit Twelve "Alex Haley" from Book 2 in English compiled by higher school teaching material compiling group in Education Ministry for Minority Preparatory students so as to introduce the application of genrebased teaching approach in English intensive reading for preparatory courses students.

\section{A. Genre analysis}

Text "Alex Haley" belongs to biography of narratives. Biography introduces the character's name, birth place, life experience and contributions etc. The hero is an African American, also called African American. He was born in the state of New York in 1921 and he has served on coastal guard team for 20 years. During the 20 years, he has acted as a journalist. In 1965, he co-wrote the biography of Malcolm X. In order to know the blacks' history including his family's history, by himself, he had a field study of the oral legends of Gambia and found his family had a long history. Based on lots of historical facts, with some proper supplements of details to make the material more complete, he accomplished the long family historical novel Root in 1916 [3-4].

(1) Genre type. According to the cultural background and interpersonal communication, the text belongs to biography of narratives. Through learning the text, the students can understand the relevant culture of African American such as Ko, a kind of African music instrument like harp. The good qualities of Alex Haley can be learned too, for example, he is hardworking and not afraid of difficulties. Everything can be accomplished as long as he keeps doing it no matter how difficult he will meet. The writing is intended for more African Americans to know their ancestor and to know their past. This book is regarded as the heritage of African Americans. Lots of people like to read it.

(2) Schema structure. The main features of biography are real and lively. The text consists four parts according to the chronic sequence. The first part introduces the background of the story including the background of hero Alex Haley's growth. He grew in Kenny of Tennessee. In his childhood, he sat by his mother, listening to the stories of his ancestor told by the elder, which paves the way to the writing long family historical novel Root. Alex Haley has offered rich material for African Americans to better understand their ancestor and their past. The black had an inferior position in past society, for they were sold to the white's family to be waiters, servants or slaves. After the black were sold, their wives, or their husbands or children can be sold to different families to make them have a separate living. The second part is the development of the story. Alex Haley finished his short college education and was drafted into coastal guard team. The dull and lonely life at sea makes him write to friends and relatives. Afterward, he wrote some articles to the magazines. After his gradual practice, he became a professional writer at the age of 37 . The third part is the climax of the story. After he became a writer, he took a great interest in the black family history, as a result, he decided to check the material to know the family history about the black, for which, he had been hardworking for 12 years. He had search and sort out the material that can be traced back to 7 generations before. The fourth part is the conclusion. With consistent efforts, Alex Haley succeeded. He created the manuscripts collected into the long novel Root which was later shot into a TV series with audience rating at about 130,000,000.

(3) Theme. Narrative has a theme. Of course, biography, one of the narrative has a theme, too. Different readers have different opinions of the same chapter. "Alex Haley" is adopted the third person to narrate. Through this narrating method, it can make the text better truth and objectivity. One characteristic of the Biography is realistic. Therefore, this writing style is consistent with the writing skill of biography. Slavery system is one of the longest and heated topic in American history. In order to better understand the history of African American, the author objectively depicted the great and toil efforts of Alex Haley. After 12 years' efforts, he finally succeeded. He wrote a long novel Root with important meaning for African American.

\section{B. Deep analysis}

Linguistic characteristics. Generally speaking, the author often uses understandable wording written language to make the content more objective and authentic. The writer uses lots of adjectives and adverbs to express the characters' feelings. For instance, the word "briefly" indicates the time Alex Haley spent in college is not long. "Lonely" shows that Alex Haley the dull life and the mood when he acted as a sailor, which foreshadows he would become a writer. "Professional" is the contrast to the amateur writer when he served on the coastal guard team. "Curious" expresses the curiosity toward the stories about his ancestors and the hope to better understand the developing history of his own clan. "Fateful" means the day of Kunta Kinte kidnapped in Africa and the day he went out to chop wood for a drum is vital. That day helped Alex Haley collect information of his ancestors, etc. Lots of adjectives and adverbs were used in text which added the color of the text and the proper use of adverbs and adjectives can help the writer describe the hero's mood.

(1) Rhetoric devices. In narratives, the author will use some rhetoric devices such as personification, simile and metaphor etc to make a text more comprehensible and more vivid. Rocking chair suggests Alex Haley lived in free and equal times. The text uses simile such as picture-like characters and metaphor like lightning bolt that suggests Alex Haley tries to make his "root" clear. The title Root also shows the earliest history of African American and suggests that African American must not forget the history and bear it in mind forever.

(2) Writing skills. The writing skills in narratives include description and narration. In the text, the author uses some words with feeling colors like curious, fascinated and fateful etc to make the passage more vivid and made the readers in the real life. A typical case is like: Alex Haley stared at the African villagers, and they stared back at their American visitor. Suddenly, the African American emerged from the crowd and began speaking. The author narrated the story according to the sequence of time. He used description and narration to write the text. 
(3) By the case analysis of genre-based approach to a biography of narrative, students are helped to know the text clues, structural model, linguistic features and writing skills etc of biography and as well as the interpersonal communication of the author. By the real case analysis teaching, the preparatory courses students has learned how to analyze the text of similar style and has reinforced the understanding about the writing characteristics of biography [5-6]. After finishing class, I will provide minority preparatory students with a text of the same genre to make them analyze the text according to the process from text structure, writing skills, linguistic characteristics, therefore, they can better understand the textual structure, writing skill and linguistic characteristics of biography---one of narrative. Through practice, minority preparatory students can better master the writing of biography---one of narrative.

\section{TEACHING FEEDBACK}

\section{A. Students'feedback}

After the case teaching based on genres, at random, I picked out 45 preparatory courses students and interviewed them with excellent record, 15 students with common performance and 15 students with poor scores. They have different opinions over the genre-based teaching approaches. The excellent students feel that the genre-based teaching approach is different from traditional teaching method which is new and can inspire them to study English and keep them be curious. To some extent, this teaching methods make the students get involved in the class and learn on their own, which abides by the requirement of current English education in China. As a result, the learning ability on their own has been enhanced and it accords with the present educational trends. They think it is worth being followed and put to use by the teachers because different teaching approaches vary according to different genres and there is not unique method in minority preparatory English teaching.

The average students also acknowledge the genre-based teaching approach. They can't adapt themselves completely to it since the teachers seldom use it. Generally speaking, few students know this teaching approach, so they need time to follow the practical use of genre-based approaches with the hope that the teachers should use more genre-based approaches in English teaching. Most of them, they are willing to adapt themselves to this method.

As to the poor students, they show the attitudes that it doesn't matter whatever teaching approaches the teachers take. For they feel they can't follow it or can't even understand it. In the English class, they hope the teachers spend more time in lecturing word, phrases and sentences because their pronunciation is good enough even to read words. Their learning ability is still on the level of words and sentences instead of the textual level. Therefore, they expect the teachers pay more attention to their English level while take the genrebase approaches.

\section{B. Teachers'feedback}

Besides students' feedback, I asked other teachers for the preparatory courses students whether they would use genrebased teaching approach in their everyday teaching in English class. Their opinions are different, too. Some said they seldom used genre-based teaching approach in their English teaching because the method is different traditional approach and they don't want to attempt to adopt a new teaching method in English teaching, and they don't know whether minority preparatory student would accept it.

Some said they occasionally adopted genre-based teaching method in their ordinary English teaching. They want to have a try a new teaching approach in English class. Sometimes they think that method is beneficial for English teaching and learning.

Some said they often would use genre-based teaching method in English class according to the text because this method can improve the teaching level and can make the students listen more attentively and interested. According to minority preparatory teacher interviewed by me, the result shows that the application of genre-based approach adds more interests for minority preparatory students in the English class and improves the class teaching level as a result.

\section{CONCLUSION}

As an English teacher in the preparatory education, I seldom used genre-based teaching approach ago. In recent years, with the teaching reformation and welcoming to assessment of my institute, I have tried to use genre-based teaching approach and gained some efficiency. Therefore, I believe, the proper use of genre-based approach in English teaching for the preparatory courses students can make the students master the skills of reading and writing. When they read or writing with problems in their mind, they can achieve high efficiency by a little effort. Therefore, the application of genre-based teaching approach in English teaching for the preparatory courses students can help improve the teaching level and enhance the learning level of the students as a result and I hope this teaching approach will be applied by more teachers and more schools or college s or universities in China. The shortcoming of this thesis is that only 45 minority preparatory students were interviewed.

\section{REFERENCES}

[1] Lan, Ma. Genre-based Teaching Approach in College English Teaching [J]. Teaching Study.2003.

[2] Xiubai, Qin.A view on the Genre-based Teaching Approaches [J]. Foreign Language Teaching and Research. 2002.

[3] Jinlong,Han\&Xiubai, Qin. Genre-based Analysis and Genre-based Teaching Approach [J]. Foreign Language Circle. 2000.

[4] Delu, Zhang. An Exploration on the Halliday's Functional Language Teaching Thoughts [J]. Foreign Language Teaching. 2004.

[5] Genre as social action Carolyn R. Miller - Quarterly Journal of Speech.

[6] An educational, or process, approach to the teaching of professional genres J Flowerdew - Elt Journal. 